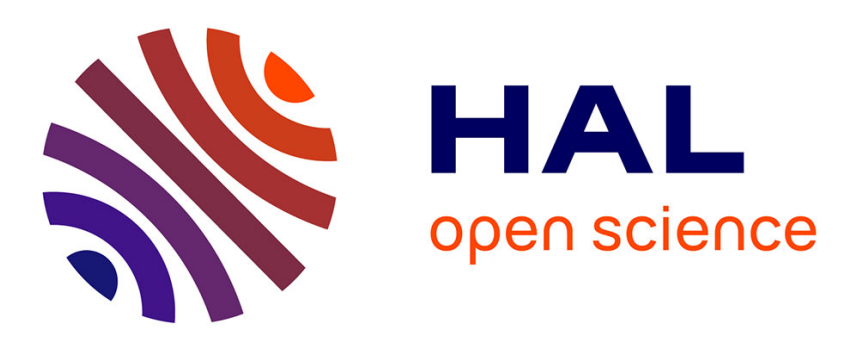

\title{
Small-cell comb foundation does not impede Varroa mite population growth in honey bee colonies
}

\author{
Jennifer A. Berry, William B. Owens, Keith S. Delaplane
}

\section{To cite this version:}

Jennifer A. Berry, William B. Owens, Keith S. Delaplane. Small-cell comb foundation does not impede Varroa mite population growth in honey bee colonies. Apidologie, 2010, 41 (1), 10.1051/apido/2009049 . hal-00892019

\section{HAL Id: hal-00892019 \\ https://hal.science/hal-00892019}

Submitted on 1 Jan 2010

HAL is a multi-disciplinary open access archive for the deposit and dissemination of scientific research documents, whether they are published or not. The documents may come from teaching and research institutions in France or abroad, or from public or private research centers.
L'archive ouverte pluridisciplinaire HAL, est destinée au dépôt et à la diffusion de documents scientifiques de niveau recherche, publiés ou non, émanant des établissements d'enseignement et de recherche français ou étrangers, des laboratoires publics ou privés. 


\title{
Small-cell comb foundation does not impede Varroa mite population growth in honey bee colonies*
}

\author{
Jennifer A. BERRY ${ }^{1}$, William B. OWENS ${ }^{2}$, Keith S. DelaPlane ${ }^{1}$ \\ ${ }^{1}$ Department of Entomology, University of Georgia, Athens, GA 30602, USA \\ ${ }^{2}$ Owens Apiaries, 4510 Springwood Drive, Monroe, GA 30655, USA
}

Received 1 October 2008 - Revised 23 March 2009 - Accepted 27 April 2009

\begin{abstract}
In three independently replicated field studies, we compared biometrics of Varroa mite and honey bee populations in bee colonies housed on one of two brood cell types: small-cell $(4.9 \pm 0.08 \mathrm{~mm}$ cell width, walls inclusive) or conventional-cell $(5.3 \pm 0.04)$. In one of the studies, ending colony bee population was significantly higher in small-cell colonies (14994 \pm 2494 bees) than conventional-cell (5653 \pm 1082$)$. However, small-cell colonies were significantly higher for mite population in brood $(359.7 \pm 87.4$ vs. $134.5 \pm 38.7$ ), percentage of mite population in brood ( $49.4 \pm 7.1$ vs. $26.8 \pm 6.7$ ), and mites per 100 adult bees $(5.1 \pm 0.9$ vs. $3.3 \pm 0.5)$. With the three remaining ending Varroa population metrics, mean trends for small-cell were unfavorable. We conclude that small-cell comb technology does not impede Varroa population growth.
\end{abstract}

Apis mellifera / Varroa destructor / IPM / comb / cell size

\section{INTRODUCTION}

The mite Varroa destructor Anderson and Trueman is a natural ectoparasite of the eastern honey bee Apis cerana F, but now parasitizes the western honey bee Apis mellifera $\mathrm{L}$. throughout much of its modern range. Mite reproduction is limited to the brood cells of its host bee, and it is clear in free-choice studies that Varroa preferentially enter comparatively large brood cells. When Message and Gonçalves (1995) compared brood reared in small worker cells produced by Africanized bees with brood reared in large cells produced by European bees, they found a 2-fold increase in mite infestation rates in the larger cells. When Piccirillo and De Jong (2003) compared Varroa infestation rates in three types of brood comb with different cell sizes (inner width), $4.84 \mathrm{~mm}, 5.16 \mathrm{~mm}$, or $5.27 \mathrm{~mm}$, they found

Corresponding author: K.S. Delaplane, ksd@uga.edu

* Manuscript editor: Peter Rosenkranz that percentage of cells infested was significantly higher in the largest cells compared to the other two groups.

These kinds of observations have led to an interest among beekeepers in downsizing comb foundations as a cultural control against Varroa. In North America, the resulting "small-cell" foundation measures $4.9 \mathrm{~mm}$ per cell (Dadant \& Sons, Hamilton, IL, USA) compared to that of conventional foundation measuring between $5.2 \mathrm{~mm}$ and $5.4 \mathrm{~mm}$. These numbers are derived by measuring the width of 10 cells in a straight line, inclusive of wall widths. In this study we challenged a null hypothesis of no difference in Varroa and bee population metrics between bee colonies housed on combs of small-cell or conventional-cell foundation.

\section{MATERIALS AND METHODS}

In three independent experimental replicates, we compared biometrics of Varroa mite and honey 
bee populations in bee colonies housed on one of two brood cell types: small-cell or conventionalcell. In spring 2006, foundation of both types was drawn during natural nectar flows prior to set up of the experiment. Small-cell foundation was drawn out by colonies containing honey bees which had themselves been reared in small-cell combs. Conventional foundation was similarly drawn out by colonies whose bees were derived from conventional combs. Once combs were drawn we determined realized cell width (walls inclusive) by counting the number of cells in $10 \mathrm{~cm}$ linear $(n=60$ samples each cell type). Cell width from small-cell combs was $4.9 \pm 0.08 \mathrm{~mm}$ and from conventional$5.3 \pm 0.04 \mathrm{~mm}$. In August 2006, bees were collected from a variety of existing colonies (irrespective of rearing history) and combined in large cages to achieve a homogeneous mixture of bees and Varroa mites. Twenty screened packages were made up, each containing ca. $2.0 \mathrm{~kg}$ (15966) bees. Packages were transported to a test apiary in Oconee County, Georgia, USA $\left(33^{\circ} 50^{\prime} \mathrm{N}, 83^{\circ} 26^{\prime} \mathrm{W}\right)$ where each was used to stock one of 20 single-story deep Langstroth hives. Ten of the hives each contained ten frames of drawn small-cell comb, and the other ten contained drawn conventional-cell comb. One alcohol sample of ca. 300 bees was collected from each package to derive starting mite: adult bee ratios and, by extrapolation, beginning mite populations (colonies were broodless so all mites were phoretic on adults). Queens from a single commercial source were introduced into colonies. All colonies received sugar syrup and pollen patties as needed. Colonies were removed from the experiment if they died or their queens failed.

In March 2007 a second experiment of twenty colonies was established in the same manner as before with the following differences: each package contained ca. $1.45 \mathrm{~kg}$ (11612) bees, and colonies were established on foundation instead of drawn comb. A third experiment was set up in April 2008, each colony with $1.36 \mathrm{~kg}$ (10886) bees and started on drawn comb of the appropriate experimental type stored from the previous year; honey was removed from combs to remove variation in beginning food stores.

In June 2007 (for colonies started in August 2006 and March 2007) and in August 2008 (for colonies started in April 2008) we collected the following ending parameters: daily mite count on bottom board sticky sheet (72-h exposure), average mites per adult bee recovered from alcohol samples (ca. 100-300 bees), mites per 100 cells of capped brood, and brood area $\left(\mathrm{cm}^{2}\right)$. A measure of ending bee population was made by summing the proportions of whole deep frames covered by bees (after Skinner et al., 2001) then converting frames of adult bees to bee populations with the regression model of Burgett and Burikam (1985). Brood area $\left(\mathrm{cm}^{2}\right)$ was converted to cells of brood after determining average cell density as 3.93 per $\mathrm{cm}^{2}$ for conventional-cells and 4.63 for small-cell. From cells of brood we calculated the number of cells sealed by applying the multiplier of 0.53 derived by Delaplane (1999). From mites on adult bees and mites in brood we could derive ending mite populations and percentage of mite population in brood a positive indicator of the fecundity of a mite population (Harbo and Harris, 1999). Finally, for the August 2006 colonies we sampled adult bees in October 2006 for average body weight.

The duration of time between experiment start date and collection of ending Varroa population metrics was ca. 40 weeks for August 2006 colonies, 12 weeks for March 2007 colonies, and 16 weeks for April 2008 colonies. A field test of no more than 9-10 weeks is adequate to accurately appraise Varroa population change (Harbo, 1996).

An initial analysis was run as a randomized block analysis of variance recognizing the three experiment start dates as blocks and using the interaction of treatment and block as test term (Proc GLM, SAS 2002-2003). There was an interaction between treatment and block for ending colony bee population, so for this variable the analysis was performed separately for each start date and residual error used as test term. Differences were accepted at the $\alpha \leq 0.05$ level and where necessary means separated by Tukey's test.

\section{RESULTS}

Significant effects of cell size were detected for ending mites in brood $(F=38.3$; df $=1,2$; $P=0.0252)$, percentage of mite population in brood cells ( $F=57.4$; df $=1,2 ; P=0.0170)$ and ending mites per 100 adult bees $(F=23.8$; df $=1,2 ; P=0.0396)$. The ending number of mites in brood, percentage of mite population in brood, and mites per 100 adult bees were significantly higher in small-cell colonies (Tab. I). There was a significant interaction between start date and treatment for ending colony bee population $(F=5.14$; df $=2,33$; $P=0.0114$ ) which is explained by the fact that 
Table I. Mean values ( \pm se) for bee and Varroa population metrics in bee colonies housed on conventionalsized brood cells or small cells. Colonies of both cell types were set up in August 2006 (15966 bees), March 2007 (11612 bees), or April 2008 (10886 bees). Ending data were collected in June 2007 (August 2006 and March 2007 colonies) and August 2008 (April 2008 colonies). A one-time measure of adult bee live weight was made October 2006 for August 2006 colonies. Numbers in parentheses $=n$. The occurrence of significant treatment effects $(\alpha \leq 0.05)$ is indicated by *.

\begin{tabular}{lll}
\hline Variable & Conventional-cell & Small-cell \\
Beginning colony mite popn. & $303.1 \pm 61.4(19)$ & $308.6 .2 \pm 54.1(21)$ \\
$\begin{array}{l}\text { Adult bee weight (mg) in October 2006 } \\
\text { (Aug. 2006 colonies only) }\end{array}$ & & $121.3 \pm 6.7(4)$ \\
Ending cm ${ }^{2}$ brood & $6320 \pm 681(19)$ & $5627 \pm 490(21)$ \\
Ending cells of brood & $24838 \pm 2675(19)$ & $26053 \pm 2271(21)$ \\
Ending mites per 24 h sticky sheet & $17.4 \pm 5.0(19)$ & $28.3 \pm 6.0(21)$ \\
Ending mites per 100 brood cells & $0.9 \pm 0.2(19)$ & $2.8 \pm 0.6(21)$ \\
Ending colony mite popn. & $409.7 \pm 93.4(18)$ & $670.5 \pm 112.5(21)$ \\
Ending mites in brood & $134.5 \pm 38.7(19)$ & $359.7 \pm 87.4(21)^{*}$ \\
Ending \% mite popn. in brood & $26.8 \pm 6.7(16)$ & $49.4 \pm 7.1(20)^{*}$ \\
Ending mites per 100 adult bees & $3.3 \pm 0.5(18)$ & $5.1 \pm 0.9(21)^{*}$ \\
\hline
\end{tabular}

Table II. Mean values ( \pm se) for ending colony bee population in bee colonies housed on conventional-sized brood cells or small cells. Colonies of both cell types were set up in August 2006 (15966 bees), March 2007 (11612 bees), or April 2008 (10886 bees). Ending data were collected in June 2007 (August 2006 and March 2007 colonies) and August 2008 (April 2008 colonies). Means for this variable are reported by experiment start date which interacted significantly with treatment. Numbers in parentheses $=n$. The occurrence of significant treatment effects $(\alpha \leq 0.05)$ is indicated by *.

\begin{tabular}{lc}
\hline $\begin{array}{l}\text { Variable } \\
\text { Ending colony bee popn. }\end{array}$ & Conventional-cell \\
August 2006 \\
\\
$5653 \pm 1082(3) \quad 14994 \pm 2494(3) *$ \\
March 2007 \\
$10960 \pm 2115(6) \quad 13717 \pm 1309(9)$ \\
April 2008 \\
$14629 \pm 1111(9) \quad 12461 \pm 2177(9)$ \\
\hline
\end{tabular}

populations tended to be higher in small-cell colonies except for the April 2008 start date. The advantage for small-cell colonies was significant for the August 2006 start date $(F=$ $11.8 ; \mathrm{df}=1,4 ; P=0.0264$ ) (Tab. II).

We failed to detect significant effects of cell size on $\mathrm{cm}^{2}$ brood, cells of brood, mites per $24 \mathrm{~h}$ sticky sheet, mites per 100 brood cells, and colony mite populations (Tab. I).

\section{DISCUSSION}

Although a significant and favorable trend for small-cell colonies was indicated for ending bee populations for the August 2006 start date (Tab. II), the chief interest in small-cell technology resides in its potential as a nonchemical limiter of Varroa population growth. By this criterion, the present results are not encouraging. The ending number of mites in brood, percentage of mite population in brood, and mites per 100 adult bees were significantly higher in small-cell colonies (Tab. I). Moreover, with all remaining ending Varroa population metrics, mean trends were unfavorable for small cell (Tab. I). We conclude that small-cell comb technology does not impede Varroa population growth. This null conclusion is reinforced by the facts that: (1) the experiment was replicated independently three times with start dates varying between spring and fall and test 
periods ranging from 12-40 weeks, (2) there were no interactions between start date and treatment for ending Varroa metrics, showing that responses were consistent across experiments, (3) the question of Varroa population growth was examined holistically with six dependent variables, and finally (4) the bar for performance should be high before a candidate technology is recommended for field use. It is worth noting that Varroa densities in this study (3.3-5.1 mites per 100 bees, Tab. I) were not within the action threshold of ca. 13 mites per 100 bees shown for the region by Delaplane and Hood (1999).

Interest in small-cell foundation has been fueled in part by observations of Martin and Kryger (2002) that conditions which constrict the space between the host pupa and male protonymph mite promote male mite mortality. However, as these authors point out, "reducing cell sizes as a mite control method will probably fail to be effective since the bees are likely to respond by rearing correspondingly smaller bees". The present study supports this deduction directly, and its premise indirectly: average bee live weight in October was numerically smaller in small-cell colonies than conventional (Tab. I).

\section{ACKNOWLEDGEMENTS}

Technical assistance was provided by Dan Harris, Cody Sorensen, Eleanor Spicer, and Nicholas Weaver.

La petite taille des alvéoles des rayons de cire n'entrave pas le développement des populations de Varroa destructor dans les colonies d'abeilles.

Apis mellifera / Varroa destructor / lutte intégrée / rayon/ taille de la cellule

Zusammenfassung - Mittelwände mit kleinen Zellen reduzieren nicht das Wachstum der Varroa-Population in Honigbienenvölkern. In Wahlversuchen konnte gezeigt werden, dass Milbenweibchen (Varroa destructor) bevorzugt größere Brutzellen von Apis mellifera befallen (Message and Gonçalves, 1995; Piccirillo and De Jong, 2003). Diese Beobachtungen stießen bei den Imkern auf großes Interesse und haben dazu geführt, dass eine
Verringerung der Zellgröße bei den Mittelwänden als eine mögliche biotechnische Kontrollmaßnahme gegen die Varroose diskutiert wurde. In Nordamerika beträgt der daraus resultierende Durchmesser für "kleine Zellgrößen" bei den Mittelwandgussformen $4,9 \mathrm{~mm}$ pro Zelle (Dadant \& Sons, Hamilton, IL, USA) im Vergleich zu normalen Zellgrößen mit 5,2 bis $5,4 \mathrm{~mm}$. Diese Werte werden ermittelt, indem 10 Zellen in Reihe einschließlich der Zellwände gemessen werden.

In Feldstudien mit drei unabhängigen Wiederholungen verglichen wir die Entwicklung der Varroa-, Bienen- und Brutpopulation bei Bienenvölkern mit zwei verschiedenen Zelltypen: Kleine Zellen (4,9 \pm $0,08 \mathrm{~mm}$ Zelldurchmesser einschließlich Zellwände) und konventionelle Zellen (5,3 $\pm 0,04 \mathrm{~mm})$. Die Versuche begannen im August 2006, März 2007 bzw. April 2008 und die letzten abhängigen Testvariablen wurden im Juni 2007 (für Völker von August 2006 und März 2007) bzw. im August 2008 (für Völker von April 2008) ermittelt. Für die im August 2006 gestarteten Versuchsvölker war die Bienen-Endpopulation in Völkern mit kleinen Zellen signifikant größer als in denen mit konventionellen Zellen $(14994 \pm 2494$ im Vergleich $\mathrm{zu}$ $5653 \pm 1082$ Bienen). Allerdings hatten die Völker mit kleinen Zellen signifikant mehr Milben in der Brut $(359,7 \pm 87,4$ vs. $134,5 \pm 38,7)$, einen höheren prozentualen Brutbefall $(49,4 \pm 7.1$ vs. $26,8 \pm 6,7)$ und mehr Milben pro 100 adulte Bienen (5,1 \pm 0.9 vs. 3,3 $\pm 0,5)$. In Anbetracht dieser Daten zur VarroaPopulationsdynamik haben kleine Zellen im Durchschnitt sogar einen nachteiligen Effekt. Wir schlieBen daraus, dass die "Kleine-Zellen-Betriebsweise" das Wachstum der Varroa-Population nicht reduziert. Diese Schlussfolgerung wird durch folgende Details der Versuche untermauert:

1. Das Experiment wurde dreimal wiederholt mit unterschiedlichen Startterminen vom Frühjahr bis zum Herbst und variablen Versuchzeiträumen von 12-40 Wochen.

2. Es gab keine Interaktionen zwischen dem Starttermin und der Variable "Zellgröße" bzgl. der Varroa-Endpopulation; dies zeigt, dass die Ergebnisse der Versuchsserien untereinander konsistent sind.

3. Das Wachstum der Varroa-Population wurde anhand von 6 unabhängigen Variablen beurteilt.

4. Die Vorteile einer neuen Technologie müssen eindeutig nachgewiesen sein, bevor diese in der Praxis empfohlen werden kann.

Abschließend sei noch bemerkt, dass der Varroabefall in diesen Untersuchungen (3,3-5,1 Milben pro 100 Bienen, Tab. I) deutlich unterhalb des Befalls von 13 Milben pro 100 Bienen liegt, der von Delaplane and Hood (1999) für diese Region als Schwellenwert für Sofortmaßnahmen ermittelt wurde.

Apis mellifera / Varroa destructor / Integrierte Schädlingsbekämpfung / Wabe / Zellgröße 


\section{REFERENCES}

Burgett M., Burikam I. (1985) Number of adult honey bees (Hymenoptera: Apidae) occupying a comb: a standard for estimating colony populations, J. Econ. Entomol. 78, 1154-1156.

Delaplane K.S. (1999) Effects of the slatted rack on brood production and its distribution in the brood nest, Am. Bee J. 139, 474-476.

Delaplane K.S., Hood W.M. (1999) Economic threshold for Varroa jacobsoni Oud in the southeastern USA, Apidologie 30, 383-395.

Harbo J.R. (1996) Evaluating colonies of honey bees for resistance to Varroa jacobsoni, BeeScience 4, 100-105.

Harbo J.R., Harris J.W. (1999) Heritability in honey bees (Hymenoptera: Apidae) of characteristics associated with resistance to Varroa jacobsoni (Mesostigmata: Varroidae), J. Econ. Entomol. 92, 261-265.
Martin S.J., Kryger P. (2002) Reproduction of Varroa destructor in South African honey bees: does cell space influence Varroa male survivorship? Apidologie 33, 51-61.

Message D., Gonçalves L.S. (1995) Effect of the size of worker brood cells of Africanized honey bees on infestation and reproduction of the ectoparasitic mite Varroa jacobsoni Oud., Apidologie 26, 381-386.

Piccirillo G.A., De Jong D. (2003) The influence of brood comb cell size on the reproductive behavior of the ectoparasitic mite Varroa destructor in Africanized honey bee colonies, Genet. Mol. Res. $2,36-42$.

SAS Institute (2002-2003) SAS/STAT user's guide, version 9.1, SAS Institute, Cary, NC, USA.

Skinner J.A., Parkman J.P., Studer M.D. (2001) Evaluation of honey bee miticides, including temporal and thermal effects on formic acid gel vapours, in the central south-eastern USA, J. Apic. Res. 40, 81-89. 